\title{
GIMDOS APVALIOJO RAIŠČIO ENDOMETRIOZE். KLINIKINIS ATVEJIS
}

\author{
Henrieta Janušonytė \\ Vilniaus universiteto Medicinos fakultetas
}

Raktažodžiai: kirkšninè endometriozė, gimdos apvalusis raištis, kirkšnies skausmas.

\begin{abstract}
Santrauka
Endometriozè - tai liga, kuri apibūdinama kaip funkcinių endometrinių liaukų ir stromos egzistavimas už gimdos ribų. Šios patologijos paplitimas tarp vaisingo amžiaus moteru yra apie 10 - 20 proc., dažniausiai pasireiškiantis dubens organuose, ypač kiaušidèse ir dubens pilvaplèveje. Iš visų endometrioze sergančių moterų tik apie 0,6 proc. pasireiškia ši patologija kirkšnies srityje, dar rečiau ji būna ant gimdos apvaliojo raiščio. Dèl tokio mažo paplitimo, kirkšnies endometriozè dažnai esti nepastebèta arba painiojama su kita patologija. Būdingiausi simptomai yra palpuojamas darinys kirkšnies srityje, skausmas jo vietoje, sustiprejantis menstruacijų metu. Šiame darbe aprašomas šios retos endometriozès formos klinikinis atvejis ir pateikiama susijusios literatūros apžvalga, norint atkreipti demesị, jog atliekant diferencinę diagnostiką, esant dariniui kirkšnyje, reiktų nepamiršti ir kirkšninès endometriozès.

Pristatomas 31 metu moters, kuri skundèsi stipriu skausmu dešinès kirkšnies srityje, klinikinis atvejis. Skausmas sustiprèdavo menstruacijų metu. Moters teigimu, skausmas kirkšnyje truko apie 5 mėnesius. Pajutusi šį simptomą, pati atliko dešinès kirkšnies apčiuopą ir užčiuope darinį. Iš pradžių skausmas buvo epizodinis, tačiau pastaraji mènesį tapo nuolatiniu. Prieš metus šalinta kiaušidès cista. Moteris negimdžiusi. Buvo atliktas ultragarsinis tyrimas. Gaktinès srities pilvo sienoje rastas 9x26×21 mm dydžio hipogeniškas, nehomogeniškas, vaskuliarizuotas darinys. Padaryta išvada, jog tai dešinès kirkšnies endometrioma. Atlikta endometriomos ekscizija ir biopsija. Nustatyta, jog endometrioma išplitusi ant gimdos apvaliojo raiščio. Histopatologinis tyrimas patvirtino endometriozès diagnozę.

Endometriozè dažnai painiojama su kitomis patologijomis, pavyzdžiui, kirkšnies išvarža, todèl neretai nediagnozuojama. Jeigu vaisingo amžiaus moteriai apčiuo-
\end{abstract}

piamas darinys kirkšnyje, net jeigu pacientė ir nejaučia tokių simptomų, kaip skausmas kirkšnies srityje, reikia atkreipti dèmesị, jog tai gali būti endometrioma ir atlikti reikiamus tyrimus. Tai gali būti ultragarsinis ar magnetinio rezonanso tyrimas, tačiau patvirtinimui būtinas histologinis ištyrimas. Gali būti skiriamas medikamentinis, konservatyvusis gydymas arba radikali operacija.

\section{Ivadas}

Endometriozè - tai liga, kuri apibūdinama kaip funkcinių endometrinių liaukų ir stromos egzistavimas už gimdos ribų. Jos atsiradimui turi reikšmès retrogradinès menstruacijos, kūno ertmes išklojančių ląstelių metaplazija, imuninès sistemos sutrikimai, genetiniai bei aplinkos ir gyvenimo būdo veiksniai [1-7]. Šios patologijos paplitimas tarp vaisingo amžiaus moterų yra apie 10 - 20 proc., dažniausiai pasireiškiantis dubens organuose, ypač kiaušidèse ir dubens pilvaplèvejje. Didžiausia tikimybè susirgti šia liga yra 30 40 metų moterims [8-10]. Endometriozė gali pasireikšti ir ne dubens organuose, pavyzdžiui, virškinamajame trakte, šlapimo takuose, krūtinès ląstoje, centrineje nervų sistemoje, kauluose, chirurginių pjūvių vietose, ir labai retai - kirkšnies srityje [11]. Iš visų endometrioze sergančių moterų tik apie $0,3-0,6$ proc. sergančiujų ši patologija pasireiškia kirkšnies srityje, dar rečiau - ant gimdos apvaliojo raiščio $[12,13]$. Dèl tokio mažo paplitimo, kirkšnies endometriozė dažnai esti nepastebèta arba painiojama su kita patologija. Būdingiausi simptomai yra palpuojamas darinys kirkšnies srityje, skausmas jo vietoje, sustiprejantis menstruacijų metu.

Tyrimo tikslas - pristatyti šios labai retos endometriozès formos klinikinį atvejị ir pateikti susijusios literatūros apžvalgą, norint atkreipti dèmesį, jog atliekant diferencinę diagnostiką, esant dariniui kirkšnyje, reikètų nepamiršti ir kirkšninès endometriozès.

\section{Klinikinis atvejis}

31 metų moteris skundèsi stipriu skausmu dešinès kirkšnies srityje. Skausmas sustiprèdavo menstruacijų metu. Moters teigimu, skausmas kirkšnyje truko apie 5 mènesius. 


\section{4}

Pajutusi šį simptomą, pati atliko dešinės kirkšnies apčiuopą ir užčiuope darinị. Iš pradžių skausmas buvo epizodinis, tačiau paskutinị ménesį tapo nuolatiniu. Tada kreipèsi ị gydymo ịstaigą.

Pasak moters, mėnesinès paprastai būdavo reguliarios, 28 dienų ciklas, trukdavo apie 5 - 7 dienas. Negimdžiusi, něštumo nutraukimo ar savaiminio persileidimo nebuvo. Menopauzè neprasidèjusi. Prieš metus laporoskopiškai šalinta kiaušidès cista. Kitų operacijų nebuvo. Lètinèmis ligomis nesirgusi. Teigè nesanti alergiška. Vartojo kontraceptines tabletes, kitų vaistų nevartojo.

Atlikta ị gydymo ịstaigą atvykusios pacientès apžiūra: ūgis - $171 \mathrm{~cm}$, svoris - $58 \mathrm{~kg}$, kūno sudejjimas normosteninis, odoje bẻrimų nebuvo. Krūtyse sukietejjimų ar mazgų nerasta.

Širdies ir kraujagyslių sistema: širdies tonai ritmiški, ūžesių neišklausoma. Arterinis kraujospūdis atvykimo metu 125/70 mmHg. Širdies susitraukimų dažnis 74 kartai per minutę.

Kvėpavimo sistema: alsavimas vezikulinis, karkalų negirdèti. Virškinimo sistema: pilvas minkštas, neskausmingas. Kepenys neužčiuopiamos, neskausmingos. Tuštinimasis normalus.

Urogenitalinè sistema: inkstai neužčiuopiami, Džordano simptomas ir kairèje, ir dešinèje neigiamas. Šlapinimosi sutrikimų nèra. Kaulų, raumenų, sąnarių sistema be pakitimų.

Dèl skausmo dešinėje kirkšnies srityje pacientei paskirtas diagnostinis kirkšnių limfmazgių ultragarsinis tyrimas (dešinès galūnės). Tyrimo metu dešiniojoje kirkšnyje nustatyti keli nespecifiniai limfmazgiai iki $9 \mathrm{~mm}$ dydžio (1 pav.). Gaktineje srityje pilvo sienoje rastas 9x26 x21 mm dydžio hipogeniškas, nehomogeniškas, vaskuliarizuotas darinys (galimas endometriozès židinys) (2 pav.). Išvada - dešiniosios kirkšnies endometrioma.

Atlikti bendrasis ir biocheminis kraujo tyrimai. Visi rodikliai buvo normos ribose, tik limfocitų (pagal ŠG normą)

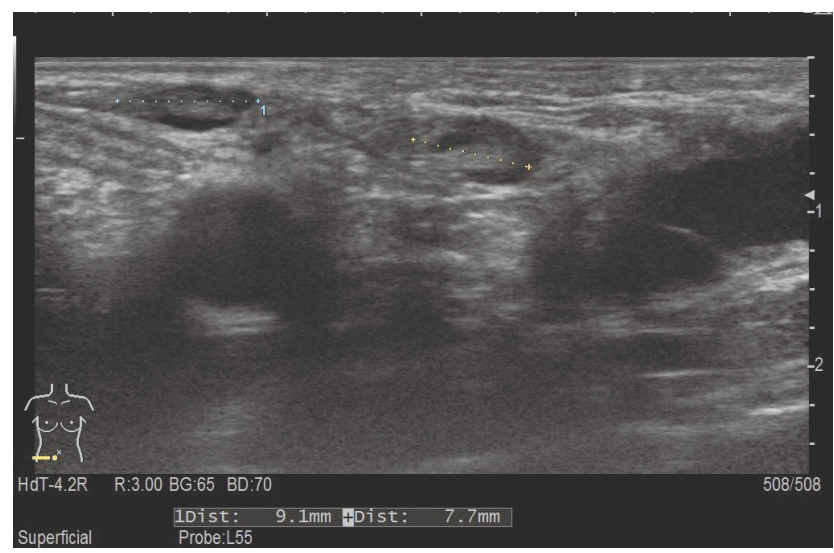

1 pav. Nespecifiniai limfmazgiai santykis padidèjęs - 42,7 proc. (norma 20,0 - 40,0\%). Nustatyta klinikinè diagnozė: kirkšnies endometrioma. Pacientė hospitalizuota planinei operacijai - kirkšnies endometriomos ekscizijai. $1 \mathrm{~cm}$ virš simfizès ir $4 \mathrm{~cm}$ ị dešinę atliktas $3 \mathrm{~cm}$ odos pjūvis. Monopoliniu ir bipoliniu koaguliatoriumi pasluoksniui išpreparuota apie 2-3 cm dydžio endometrioma dešiniojo kirkšnies kanalo išorinėse žiomenyse ant dešiniojo apvaliojo raiščio. Atlikta endometriomos ekscizija. Preparatas išsiųstas histopatologiniam tyrimui.

Po operacijos pacientė keletą dienų skundèsi nežymiu maudimu pjūvio vietoje. Išrašant būklè buvo patenkinama, nusiskundimų nebuvo. Skirtos rekomendacijos: 2 savaites riboti fizinị krūvị, vartoti nuskausminamuosius pagal poreikị, po savaites kreiptis ị šeimos gydytoją kontrolei. Vèliau buvo gautas histopatologinis atsakymas. Mikroskopinis aprašymas: fibrozinio riebalinio audinio fragmentai su negausiais šeivinių ląstelių stromos židiniais ir vienasluoksniu kuboidiniu epiteliu išklotomis liaukomis. Jungiamajame audinyje vietomis matyti siderofagai. Imunohistocheminio tyrimo aprašymas: šeivinių ląstelių stroma CD10 (+), liaukas išklojantis epitelis ir stroma ER $(+)$. Klinikinè diagnozė patvirtinta: kirkšnies endometrioma. Operacijos metu ir atlikus histopataloginį tyrimą buvo rasta, jog endometriozé yra ant gimdos apvaliojo raiščio.

\section{Aptarimas}

Moters amžius, nusiskundimai ir ligos anamnezè atitinka literatūros duomenis $[8,9,11]$. Kirkšninès endometriozès patogenezè yra panaši ị dubens endometriozès patogenezę. I. Clausen ir K. Nielsen [14] pasiūlè kelias galimas kirkšninès endometriozès patogenezès teorijas. Pasak jų, būtent šie procesai yra svarbūs: endometro ląstelių implantacija kirkšnies srityje dèl retrogradinių menstruacijų; metastazès, plintančios limfagyslèmis arba venomis; Miulerinio latako embriono ląstelių igimta hormonų aktyvacija; mezotelio

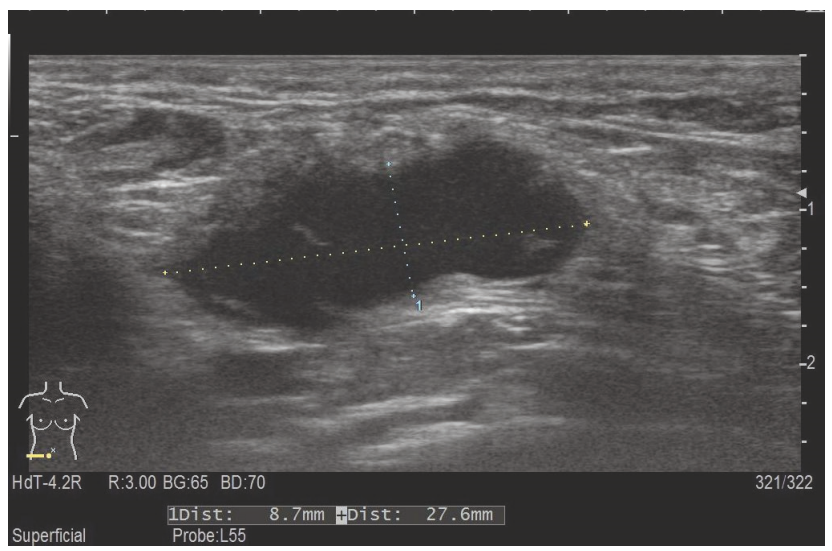

2 pav. Endometriozès židinys 
ląstelių metaplazija ir ekstencija iš dubens išilgai apvaliojo raiščio. Kirkšninė endometriozė daug dažniau pasireiškia dešinèje pusèje, negu kairèje, neretai siejama su kirkšnine išvarža, nes ir šios atveju kirkšnyje čiuopiamas kietas darinys, jaučiamas skausmas, matomas tinimas. Kirkšninė išvarža dažnai pasireiškia dėl užpakalinès kirkšnies kanalo sienos silpnumo (dèl giliojo kirkšnies žiedo, pro kurị išlenda žarnos dalis). Endometriozès pasireiškimas abiejose pusėse labai retas $[15,16]$. Kodèl ši liga dažniau pasireiškia dešinėje pusėje - neaišku. Z. Sun ir kiti [17] pasiūlè dvi skirtingas teorijas: 1) riestinè gaubtinė žarna apsaugo kirkšnies kanalą; 2) endometriumo ląstelès dešinèje išsilaiko ilgesnị laiką dèl laikrodžio rodyklès kryptimi tekančio intraperitoninio skysčio.

Diagnozuoti endometriozę, ypač kirkšnyje, gana sunku, neretai ji būna besimptomè $[18,19]$. Pristatomu atveju pacientei pasireiškẻ dažnesnioji kirkšninès endometriozès forma dešinèje pusèje.

Diferencinè diagnostika yra labai svarbi, kuomet čiuopiama kirkšninè masè. Jos priežastys gali būti įvairios: išvarža, limfadenopatija, neuroma, pūlinys, hematoma, limfoma, lipoma, sarkoma, poodinès cistos, véžys. Kirkšninei endometriozei esant ant gimdos apvaliojo raiščio ypač didelè galimybė ją supainioti su kirkšnies išvarža [20,21]. Tokiu atveju naudinga atlikti šiuos tyrimus: kompiuterinę tomografiją, magnetinio rezonanso tyrimą, ultragarsinį tyrimą. Kompiuterinè tomografija kirkšninès endometriozès atveju nèra pats geriausias tyrimas, nes nèra specifinis, parodantis tą pati tankị, kaip ir raumens. Magnetinio rezonanso tyrimas šiuo atveju yra tikslesnis, negu kompiuterine tomografija, daugiau padedantis diferencinei diagnostikai [22,23]. M. Gaeta ir kiti [24] aprašè du magnetinio rezonanso tyrimo modelius kirkšninei endometriozei. Pirmo tipo modelis susideda iš cistinių hiperintensinių pažeidimų abiejuose režimuose T1 ir T2. Antro tipo modelio pažeidimams būdingi kieti komponentai, kurie yra hiperintensiniai T1 režime ir (arba) hipointensiniai, arba silpni hiperintensiniai T2 režime.

Šiuolaikinis ultragarsinis tyrimas edometrozès diferencinei diagnostikai yra svarbus [25]. Ultragarsinio tyrimo radiniai yra kintantys. Dažnai aptinkami apvalūs cistiniai dariniai, reiškiantys intracistinị kraujavimą, susijusị su menstruacijomis, tačiau būta atvejų, kai aptinkami hipoechogeniški, nehomogeniški arba homogeniški, kieti arba ir kieti, ir cistiniai dariniai [26,27]. Aprašomuoju atveju pacientei aptiktas hipoechogeniškas, nehomogeniškas, vaskuliarizuotas kietas darinys.

Esant cistinių darinių, juos reikia diferencijuoti su kirkšnine išvarža, o kietus darinius su sarkoma, limfoma, hematoma, pūliniais. Vaizdo instrumentiniai metodai nèra specifiniai kirkšninei endometriozei, todèl šios diagnozès patvirtinimui reikètų atsižvelgti i pacientès patiriamą skausmą, ir ar paprastai menstruacijų metu jis būdingas $[24,28]$. Aprašomuoju atveju paciente patyrė ypač stiprų skausmą, kuris nebuvo būdingas anksčiau menstruacijų metu. Kai kuriais atvejais diagnozès patvirtinimui ir piktybiškumo atmetimui gali būti naudingas priešoperacinès aspiracijos citologinis tyrimas $[28,29]$.

Pacientems, sergančioms kirkšnine endometrioze, praeityje galèjo būti atliktos ginekologinès ar pilvo operacijos [21]. Jei pacientė nepatyré jokių operacijų, kirkšninė endometriozè gali būti supainiota su kita patologija ir jai gydyti paskirtas bendrasis gydytojas chirurgas. Mūsų atveju pacientès ginekologinė anamnezè rodo prieš metus atliktą laparoskopinę operaciją - kiaušidès cistos šalinimą. Bet net jeigu jai ir nebūtų atlikta ši operacija, labai svarbu neatmesti kirkšninès endometriozès diagnozès.

Kirkšninès endometriozės gydymui dažniausiai skiriama edometriomos ekscizija $[16,17]$. Operuojamas kirkšninis kanalas, per kurị eina svarbios struktūros, tad svarbu nieko nepažeisti, nes gali pasireikšti komplikacijos: nervų užspaudimas, neuralgija, hematoma. Kirkšniniame kanale yra ileoingvinalinis ir genitofemoralinis nervai, apvalusis gimdos raištis. Ileoingvinalinis nervas išeina iš $\mathrm{L} 1$ segmento ir suteikia jutimus šiose srityse: priekinèje tarpvieteje, viršutinejje šlaunies dalyje, didžiosiose lytinèse lūpose, gaktoje. Genitofemoralinis nervas išeina iš L1 - L2 segmentų ir inervuoja lytines lūpas. Po operacijos galima skirti hormonų terapiją, norint išvengti endometriozès pasikartojimo [30]. Aprašytosios pacientès atveju buvo atlikta endometriomos ekscizija. Hormonų terapija neskirta. Net ir radikali operacija nèra garantija, kad endometriozé neatsinaujins [3,22].

\section{Išvados}

1. Endometriozė yra dažna moterų liga, tačiau kirkšninė endometriozè ant gimdos apvaliojo raiščio yra labai reta patologija, pasireiškianti mažiau nei 0,6 proc. vaisingo amžiaus moterų. Ji dažnai painiojama su kitomis patologijomis, pavyzdžiui, kirkšnies išvarža, todèl neretai nediagnozuojama.

2. Atvejais, kai vaisingo amžiaus moteriai apčiuopiamas darinys kirkšnyje, net jeigu pacientè ir nejaučia tokių simptomų, kaip skausmas kirkšnies srityje, reikia atkreipti dèmesị, jog tai gali būti endometrioma, ir atlikti reikiamus tyrimus. Tai gali būti ultragarsinis ar magnetinio rezonanso tyrimas, tačiau patvirtinimui būtinas histologinis ištyrimas. Gali būti skiriamas medikamentinis konservatyvusis gydymas arba radikali operacija.

\section{Literatūra}

1. Giudice LC, Kao LC. Endometriosis. Lancet 2004; 364:17891799.

https://doi.org/10.1016/S0140-6736(04)17403-5 
2. Szyllo K, Tchorzewski H, Banusik M. et al. The involvement of T lymphocytes in the pathogenesis of endometriotic tissues overgrowth in women with endometriosis. Mediators of Inflammation 2003;12:131-138.

https://doi.org/10.1080/0962935031000134842

3. Rolla E. Endometriosis: advances and controversies in classification, pathogenesis, diagnosis, and treatment. 2019. https://doi.org/10.12688/f1000research.14817.1

4. Vigano P, Somigliana E, Vignali M. et al. Genetics of endometriosis: current status and prospects. Frontiersin Biosciiences 2007; 12: 3247- 3255 .

https://doi.org/10.2741/2308

5. Guo SW. Epigenetics of endometriosis. Molecular human reproduction 2009; 15: 587-607.

https://doi.org/10.1093/molehr/gap064

6. Sourial S, Tempest N, Hapangame DK. Theories on the pathogenesis of endometriosis. International Journal of Reproductive Medicine 2014.

https://doi.org/10.1155/2014/179515

7. Parazzini F, Chiaffarino F, Surace M. et al. Selected food intake and risk of endometriosis. Human Reproduction 2004; 19 : 1755-9.

https://doi.org/10.1093/humrep/deh395

8. Mehedinti C, Plotogea MN, Ionescu S, et al. Endometriosis still a challenge. Journal of Medicine and Life 2014;15:349-357.

9. Vercellini P, Vigano P, Somigliana E. et al. Nature reviews endocrinology 2014; 10:261-275.

https://doi.org/10.1038/nrendo.2013.255

10. Zondervan KT, Becker CM, Misser SA. Endometriosis. New England Journal of Medicine 2020; 382:1244-1256.

https://doi.org/10.1056/NEJMra1810764

11. Davis AC, Goldberg JM. Extrapelvic endometriosis. Seminars in Reproductive Medicine 2017; 35:98-101. https://doi.org/10.1055/s-0036-1597122

12. Burney RO, Giudice LC. Pathogenesis and pathophysiology of endometriosis. Fertility and Sterility 2012;98:511-519. https://doi.org/10.1016/j.fertnstert.2012.06.029

13. Tran-Harding K, Nair RT, Dawkins A, et al. Endometriosis revisited: an imaging review of the usual and unusual manifestations with pathological correlation. Clinical Imaging 2018;52:163-171.

https://doi.org/10.1016/j.clinimag.2018.07.017

14. Clausen I, Nielsen KT. Endometriosis in the groin. International Journal of Gynaecology and Obstetrics 1987;25:469-471. https://doi.org/10.1016/0020-7292(87)90064-6

15. Lim MC, Choi JY, Lee DO. et al. Inguinal endometriosis connected to intraperitoneal round ligament: complete excision with extraperitoneal wide dissection. Korean Journal of Obstetrics and Gynecology 2008;51:1533-1538.

16. Fedele L, Bianchi S, Frontino G, et al. Radical excision of inguinal endometriosis. Obstetrics and Gynecology 2007;110:530-533. https://doi.org/10.1097/01.AOG.0000268803.84556.0b

17. Sun ZJ, Zhu L, Lang JH. A rare extrapelvic endometriosis: inguinal endometriosis. Journal of Reproductive Medicine 2010;55:62-66.

18. Fauconnier A, Chapron C, Dubuisson JB. et al. Relation between pain symptoms and the anatomic location of deep infiltrating endometriosis. Fertility and Sterility 2002;78:719. https://doi.org/10.1016/S0015-0282(02)03331-9

19. D'Hooghe TM, Mihalyi AM, Simsa P, et al. Why we need a noninvasive diagnostic test for minimal to mild endometriosis with a high sensitivity. Gynecologic and Obstetric Investigation 2006; 62,136-138.

https://doi.org/10.1159/000093120

20. Mashfiqul MA, Tan YM, Chintana CW. Endometriosis of the inguinal canal mimicking a hernie. Singapore Medical Journal 2007;48:e157.

21. Wong WS, Lim CE, Luo X. Inguinal endometriosis: an uncommon differential diagnosis as on inguinal tumor. ISRN Obstetrics and Gynecology 2011.

https://doi.org/10.5402/2011/272159

22. Hiroaki N, Hiroaki T, Tetsuya K. et al. Clinical characteristics and surgical treatment for inguinal endometriosis in young women of reproductive age. Digestive Surgery 2019;36:166-172. https://doi.org/10.1159/000489827

23. Chamie LP, Ribeiro D, Tiferes DA, et al. Atypical sites of deeply infiltrative endometriosis: clinical characteristics and imaging findings. Radiografics 2018;38-309-328. https://doi.org/10.1148/rg.2018170093

24. Gaeta M, Minutoli F, Mileto A, et al. Nuck canal endometriosis: MR imaging findings and clinical features. Abdominal Imaging 2010;35:737-741. https://doi.org/10.1007/s00261-010-9607-7

25. Bean E, Chagpar P, Thanasis N, et al. Intra-and interobserver reproducibitily of pelvic ultrasound for the detection and measurement of endometriotic lesions. Human Reproduction Open 2020.

https://doi.org/10.1093/hropen/hoaa001

26. Chapron C, Marcellin L, Borghese B, Santulli P. Rethinking mechanisms diagnosis and management of endometriosis. Nature Reviews Endocrinology 2019; 15:666-682. https://doi.org/10.1038/s41574-019-0245-z

27. Guerriero S, Saba L, Pascual MA, et al. Transvaginal ultrasound vs magnetic resonance imaging for diagnosing deep infiltrating endometriosis: systematic review and metaanalysis. Ultrasound in Obstetrics and Gynecology 2018; 51:586-595. https://doi.org/10.1002/uog.18961

28. Yang DM, Kim HC, Ryu JK, et al. Sonographic findings of inguinal endometriosis. Journal of Ultrasound in Medicine 2010;29:105-110. https://doi.org/10.7863/jum.2010.29.1.105 
29. Catalina-Fernández I, Lopez-Presa D, Saenz-Santamaria J. Fine needle aspiration cytology in cutaneous and subcutaneous endometriosis. Acta Cytologica 2007;51:380-384.

https://doi.org/10.1159/000325751

30. Lee SE, Jo DH, Moon SH, et al. A case of inguinal endometriosis in the absence of previous gynecologic surgery. Korean Journal of Obstetrics and Gynecology 2008;51:261-264.

\section{ENDOMETRIOSIS OF THE UTERINE ROUND LIGAMENT. CASE REPORT H. Janušonytè}

Keywords: inguinal endometriosis, round ligament, inguinal pain.

\section{Summary}

Endometriosis is defined as the presence of functional endometrial glands and stroma outside the uterine cavity. It's prevalence in fertile women is $10-20 \%$, most likely to occur in pelvis, especially in ovaries and pelvis peritoneum. From all the women with endometriosis only $0,6 \%$ have inguinal endometriosis, and even more unlikely it is to happen on the round ligament. Due to its rarity endometriosis is often misdiagnosed. Symptoms include: palpable mass in the inguinal area associated with pain that gets more intense during menstruation. Here is presented a rare inguinal endometriosis case on the round ligament and analysis of lite- rature, in order to not reject inguinal endometriosis when making differential diagnosis.

31 year old woman was complaining of strong pain in the right inguinal area. The pain was getting stronger during menstruation. The pain had been lasting for 5 months. Patient felt a palpable mass in the inguinal area. The pain got chronic. A year ago she had an ovarian cyst removal. Patient never gave birth. Ultrasonoscopy results: 9x26x21 mm hypogenic, non-homogenic, vascularised mass on the right side. Inguinal endometriosis was suspected. Excision and byopsy of endometrioma was performed. It was found that it is extended on the round ligament. The results of histopathology revealed it was indeed inguinal endometriosis.

Endometriosis is often misdiagnosed with inguinal hernia. So if a woman of premenopausal age has a palpable inguinal mass, even if she is asymptomatic, inguinal endometriosis must be suspected and measurments must be taken. For diagnosis coud be used ultrasonography for instance. As far as treatment is concerned, it could be pharmacological (mostly hormonal) or surgical (conservative or radical).

Correspondence to: j.henrieta@gmail.com

Gauta 2021-04-10 